\title{
Overlooked runaway feedback in the marine nitrogen cycle: the vicious cycle
}

\author{
A. Landolfi, H. Dietze, W. Koeve, and A. Oschlies \\ GEOMAR Helmholtz-Zentrum für Ozeanforschung Kiel, Marine Biogeochemical Modelling, \\ Düsternbrooker Weg 20, 24105 Kiel, Germany
}

Correspondence to: A. Landolfi (alandolfi@geomar.de)

Received: 28 June 2012 - Published in Biogeosciences Discuss.: 23 July 2012

Revised: 10 January 2013 - Accepted: 11 January 2013 - Published: 1 March 2013

\begin{abstract}
The marine nitrogen (N) inventory is thought to be stabilized by negative feedback mechanisms that reduce $\mathrm{N}$ inventory excursions relative to the more slowly overturning phosphorus inventory. Using a global biogeochemical ocean circulation model we show that negative feedbacks stabilizing the $\mathrm{N}$ inventory cannot persist if a close spatial association of $\mathrm{N}_{2}$ fixation and denitrification occurs. In our idealized model experiments, nitrogen deficient waters, generated by denitrification, stimulate local $\mathrm{N}_{2}$ fixation activity. But, because of stoichiometric constraints, the denitrification of newly fixed nitrogen leads to a net loss of N. This can enhance the $\mathrm{N}$ deficit, thereby triggering additional fixation in a vicious cycle, ultimately leading to a runaway $\mathrm{N}$ loss. To break this vicious cycle, and allow for stabilizing negative feedbacks to occur, inputs of new $\mathrm{N}$ need to be spatially decoupled from denitrification. Our idealized model experiments suggest that factors such as iron limitation or dissolved organic matter cycling can promote such decoupling and allow for negative feedbacks that stabilize the $\mathrm{N}$ inventory. Conversely, close spatial co-location of $\mathrm{N}_{2}$ fixation and denitrification could lead to net $\mathrm{N}$ loss.
\end{abstract}

\section{Introduction}

Variations in the oceanic fixed-nitrogen $(\mathrm{N})$ inventory are known to have driven marine productivity changes contributing to atmospheric $\mathrm{CO}_{2}$ variations in Earth's history (Falkowski, 1997; Altabet et al., 2002). For the last several thousand years, however, the apparent stability of the $\mathrm{N}$ inventory over several oceanic $\mathrm{N}$ residence timescales (Gruber, 2004; Altabet, 2007) suggests an approximate balance of the main $\mathrm{N}$ source, the diazotrophic fixation of $\mathrm{N}_{2}$ gas, and the main $\mathrm{N}$ loss process associated with organic matter remineralization under low oxygen concentrations, referred to as denitrification (Devol et al., 2008). The N inventory is thought to be stabilized by feedback mechanisms (Codispoti, 1989) that limit and reduce the strong excursions of the marine $\mathrm{N}$ content with respect to the more slowly overturning P inventory (Delaney, 1998). The current paradigm assumes that slowly-growing $\mathrm{N}_{2}$ fixers (Capone et al., 1997) have a competitive advantage over non-fixing phytoplankton in waters where $\mathrm{N}$ is in deficit relative to phosphate (Redfield et al., 1963; Tyrrel, 1999). As a "side effect" of adding $\mathrm{N}$ without any equivalent $\mathrm{P}$, diazotrophs tend to reduce their own niche (Fig. 1a) (Tyrrel, 1999). Similarly, denitrification limits itself by reducing the amount of fixed nitrogen eventually upwelling into the light-lit layer, and thereby reducing the growth of "ordinary" phytoplankton, subsequent export of organic matter, oxygen consumption and, eventually, denitrification at depth (Fig. 1b) (Codispoti, 1989). Individually, both nitrogen fixation and denitrification initiate negative feedbacks that limit $\mathrm{N}$ inventory excursions and act as self-limiting processes (Codispoti, 1989; Gruber, 2004) (Fig. 1a, b). Mutual interactions of these antagonistic processes further work against the development of substantial N deficits or surpluses relative to P (Codispoti, 1989; Tyrrel, 1999; Gruber, 2004). According to this picture, any $\mathrm{N}$ deficit resulting from denitrification also gives rise to an excess of phosphate relative to nitrate which tends to stimulate the growth of $\mathrm{N}_{2}$ fixers (Fig. 1a) (Redfield et al., 1963; Tyrrel, 1999). $\mathrm{N}$ addition via $\mathrm{N}_{2}$ fixation enhances the export of organic matter and oxygen consumption at depth which, in turn, will enhance the loss of fixed $\mathrm{N}$ via denitrification 
(Fig. 1b) (Codispoti, 1989). Traditionally, the two processes were considered to be spatially disconnected in the current ocean because of factors such as iron limitation (Moore et al., 2009), possible temperature limits (Breitbarth et al., 2007) and macro-nutrient effects (Mills and Arrigo, 2010) that reduce the ability of diazotrophs to respond locally to $\mathrm{N}$ deficits (Redfield et al., 1963; Codispoti, 1989; Falkowski, 1997; Tyrrel, 1999; Lenton and Watson, 2000; Moore and Doney, 2007; Mills and Arrigo, 2010). The wider the spatial separation, the longer the response time and the larger the potential for changes in the marine $\mathrm{N}$ inventory. This view of a remote connection between these two counteracting processes has been difficult to reconcile with the apparent stability of the marine N inventory (Gruber, 2004; Altabet, 2007). More recently, contrasting observational inferences of a close spatial proximity of $\mathrm{N}_{2}$ fixers and denitrification in the eastern South Pacific (Deutsch et al., 2007; Fernandez et al., 2011) have been interpreted as a welcome indication (Deutsch et al., 2007; Fernandez et al., 2011; Knapp, 2012) of a fast and stabilizing feedback mechanism promoting a balanced $\mathrm{N}$ inventory (Gruber, 2004). In spite of the on-going debate on the geographic location and global rates of $\mathrm{N}_{2}$ fixation in the current ocean, the full implications of the recently suggested close spatial association of $\mathrm{N}_{2}$ fixation and denitrification on the marine $\mathrm{N}$ inventory have not been assessed.

Here we investigate the implications of spatial coupling of denitrification and $\mathrm{N}_{2}$ fixation in a state-of-the-art coupled biogeochemical (Schmittner et al., 2008) circulation model (Gnanadesikan et al., 2006). A number of sensitivity experiments examine how different parameterizations of the marine $\mathrm{N}$ cycle, specifically designed to differ in the mutual interaction of nitrogen fixation and denitrification, allow the model to maintain the marine $\mathrm{N}$ inventory. We assess the implications of our finding on the current understanding of the marine $\mathrm{N}$ inventory controls.

\section{Methods}

The coupled ocean-ice model used here corresponds to the CM2.1 (Gnanadesikan et al., 2006) configuration with a $3^{\circ} \times$ $2^{\circ}$ lateral grid resolution and 28 vertical levels. The model is forced by monthly heat and freshwater fluxes and wind fields taken from the climatological dataset of the Coordinated Ocean Reference Experiments (CORE), which is based on the work of Large and Yeager (2004). The circulation model is initialized with annual mean temperature and salinity from the World Ocean Atlas 2001 (Conkright et al., 2002). After a $20 \mathrm{yr}$ integration, the circulation model is coupled online to a modified version of the NPZD-type ecosystem model of Schmittner et al. (2008) initialized with observed nutrient and oxygen distributions (Conkright et al., 2002). The ecosystem model has 10 prognostic variables: dissolved oxygen, nitrate, phosphate, (non-nitrogen-fixing) "ordinary" phytoplankton, nitrogen-fixing phytoplankton (diazotrophs),
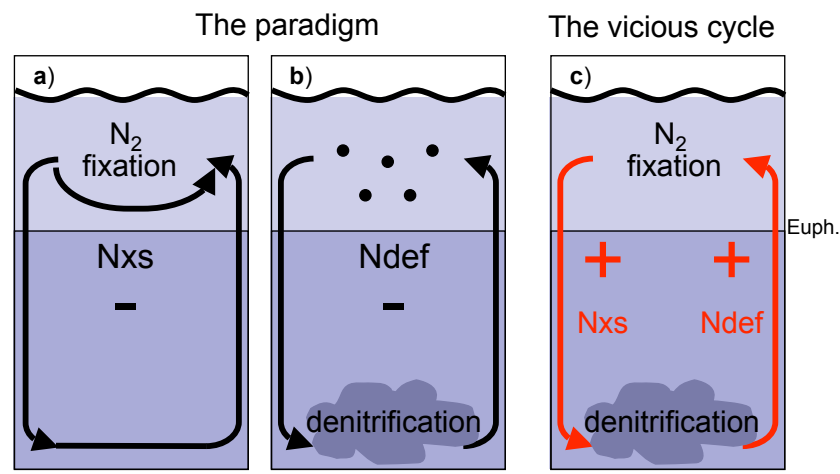

The broken vicious cycle
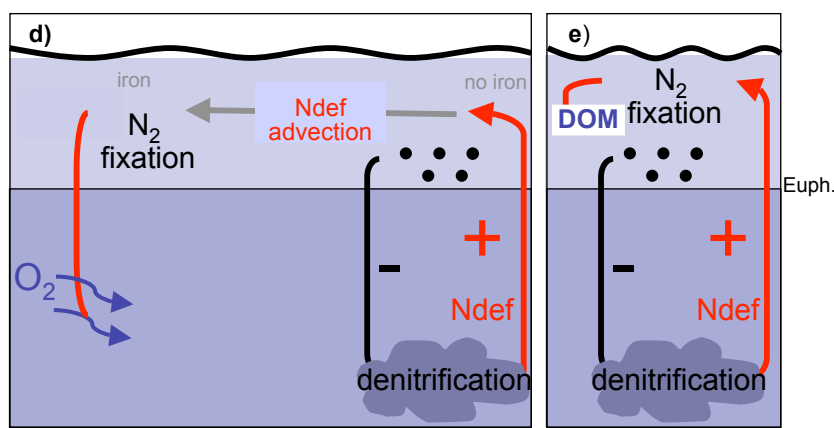

Fig. 1. Feedbacks in the marine nitrogen cycle. Negative feedbacks (black) reduce the initial perturbation. Positive feedbacks (red) amplify the initial perturbation. Negative feedbacks ensue when two process occur individually: (a) $\mathrm{N}_{2}$ fixation is self-limited via production of excess nitrogen (Nxs), and (b) denitrification, is selflimited by the generation of nitrogen deficits (Ndef) that reduce non-fixing phytoplankton export production. If denitrification and $\mathrm{N}_{2}$ fixation are spatially coupled, then the stoichiometric imbalance between the amount of $\mathrm{NO}_{3}^{-}$used up in the denitrification process versus the amount of $\mathrm{N}$ gained from the remineralization of $\mathrm{N}_{2}$ fixation-derived organic matter results is a net loss of fixed $\mathrm{N}$ that further stimulates $\mathrm{N}_{2}$ fixation, leading to a vicious cycle consisting of positive feedbacks between the two processes (c). This is because 120 moles of nitrate per mole of phosphorus are used to remineralize Redfield organic matter via denitrification, whereas only 16 moles of nitrogen (per mole phosphorus) are gained during $\mathrm{N}_{2}$ fixation. Thus, denitrification of newly fixed organic matter naturally leads to more $\mathrm{NO}_{3}^{-}$loss than $\mathrm{N}$ gained for any realistic organic matter stoichiometry (see $R_{\mathrm{N}_{\text {loss }}}$ equation in main text). To break the vicious cycle and allow for the self-limiting individual processes of panels (a) and (b) to dominate, a spatial decoupling of areas of $\mathrm{N}_{2}$ fixation and denitrification is required. This decoupling can either occur laterally (d) or vertically (e), mediated by effects of iron limitation, dissolved organic matter and oxygen injections. Light shading represents the euphotic zone and dark shading the low-oxygen waters where denitrification can take place. Black dots represent "non-fixing" phytoplankton. Positive and negative signs and red and black arrows represent positive and negative feedback, respectively. 
zooplankton and particulate phosphorus and nitrogen detritus, and, in sensitivity experiment DOM, semi-labile dissolved organic phosphorus and nitrogen. Diazotrophs are modelled explicitly. Their growth obeys rules similar to those of non-fixing phytoplankton with a temperature dependence of maximum growth rates and light and nutrient limitations. Specifically, they have a maximum growth rate lower than that of "ordinary" phytoplankton. They can take up nitrate but are only limited by phosphate. Wherever simulated oxygen concentrations fall below $5 \mathrm{mmolm}^{-3}$, nitrate is used as electron acceptor to remineralize organic matter through the process of denitrification (Devol et al., 2008). In this study, sedimentary denitrification is not considered as we do not adequately resolve shelf and coastal seas. A detailed model description is given in the Appendix.

The simulations performed are: (1) BASELINE is our simplest model configuration. Non-fixing phytoplankton and diazotrophs are limited only by light and by macronutrients, as in the original model of Schmitter et al., 2008. (2) NOFIX is identical to the BASELINE simulation except that $\mathrm{N}_{2}$ fixation is switched off. (3) IRON is identical to the BASELINE simulation except that it includes a formulation mimicking iron stress on diazotrophs and non-fixing phytoplankton. Specifically, phytoplankton and diazotroph growth rates are multiplied by factors of 0.5 and 0.2 , respectively, when modelled surface $\mathrm{PO}_{4}^{-3}$ concentrations are lower than observed monthly-mean $\mathrm{PO}_{4}^{-3}$ values taken from the World Ocean Atlas (WOA) (Conkright et al., 2002) (Fig. A1). Without an explicit representation of iron, this is to dynamically mimic the effects of iron limitation in regions such as the high nutrient low chlorophyll (HNLC) regions, where WOA surface inorganic nutrients are not completely drawn down. (4) DOM is a simulation that, in addition to the iron limitation formulation, includes DON and DOP compartments and allows diazotrophs to use DOP as a P source when phosphate concentrations are lower than $5 \mu \mathrm{mol} \mathrm{Pm}{ }^{-3}$. To investigate the impacts and relative magnitude of feedback processes linking nitrogen fixation and denitrification, which act on timescales much shorter than the several thousand years needed for a global biogeochemistry-circulation model to reach equilibrium, we start from observed present-state biogeochemical tracer distributions and limit our model integration time to 150 years. As the circulation field and initial conditions are identical in all our simulations, we interpret the relative differences among model simulations emerging from the differences in the biogeochemical model formulations. Our approach of considering the first $150 \mathrm{yr}$ of transient solutions started from observed tracer distributions should ensure that locations and intensities of the tentative feedback processes are closely representative to those one would expect to observe in the real ocean if the biogeochemical controls prescribed in the respective model configuration were correct. While we cannot rule out that even the most realistic biogeochemical model will display a long-term drift away from initial conditions, mainly because of errors in the underlying circulation field, all differences between the model simulations investigated here can be attributed entirely to differences in the biogeochemistry components of the coupled biogeochemical-physical models.

\section{Results and discussion}

All simulations display high biological production in the upwelling regions of the equatorial Eastern Pacific, the Indian Ocean and the Benguela upwelling system. These regions are associated with high export, subsequent remineralization and oxygen consumption at depth, contributing to maintain the oxygen minimum zones (OMZs) in the Pacific and Indian Ocean.

In our BASELINE model configuration, which does not account for iron limitation, competition with faster growing non-fixing phytoplankton make $\mathrm{N}$ deficiency the essential control on the growth of diazotrophs. Waters deficient in nitrate relative to Redfield phosphorus equivalents provide an ecological niche for the simulated diazotrophs. Denitrification and $\mathrm{N}_{2}$ fixation are free to interact. Thereby, simulated $\mathrm{N}_{2}$ fixation can quickly respond to the $\mathrm{N}$ deficit of denitrified waters upwelled from low-oxygen regions. Areas of simulated $\mathrm{N}_{2}$ fixation are located mainly along the eastern boundaries of the tropical ocean (Fig. 2a), in close agreement with recent inferences based on observed biogeochemical tracer distributions (Deutsch et al., 2007). Diazotrophs coexist with non-fixing phytoplankton in the upwelling regions even though surface nitrate is not completely drawn down (Fig. 3a), contributing up to $40 \%$ to total carbon assimilation (Fig. 3c). In these regions diazotrophs take up nitrate (Fig. 4a) that represents on average $5 \%$ of their $\mathrm{N}$ source. Despite the fast response of $\mathrm{N}_{2}$ fixation to the $\mathrm{N}$ deficit generated by denitrification, the total $\mathrm{N}$ inventory rapidly decreases in the BASELINE run by about $6.4 \%$ within $150 \mathrm{yr}$ (Fig. 5a). In fact, simulated denitrification rates exceed $\mathrm{N}_{2}$ fixation rates by more than a factor 4 within a few years after having initialized the model with observed tracer distributions (Fig. 5c). A systematic loss of fixed nitrogen has also been found in earlier modeling studies (Moore and Doney, 2007; Schmittner et al., 2008) and will here be explained by a positive and previously overlooked feedback: the extra production and export of organic matter associated with newly fixed nitrogen enhances denitrification (Fig. 5b) which, in turn, enhances the nitrate deficit and favours further $\mathrm{N}_{2}$ fixation above the OMZ (Fig. 1c). Because of the stoichiometric imbalance between the amount of $\mathrm{NO}_{3}^{-}$used up in the denitrification process versus the amount of $\mathrm{N}$ derived from the remineralization of organic matter originated from $\mathrm{N}_{2}-$ fixation, a net $\mathrm{N}$ loss occurs whenever newly fixed organic $\mathrm{N}$ is denitrified. Subsequent upwelling of the $\mathrm{N}$ deficit further stimulates $\mathrm{N}_{2}$ fixation. The persistence of these positive feedbacks can lead to a vicious cycle with a net loss of fixed 

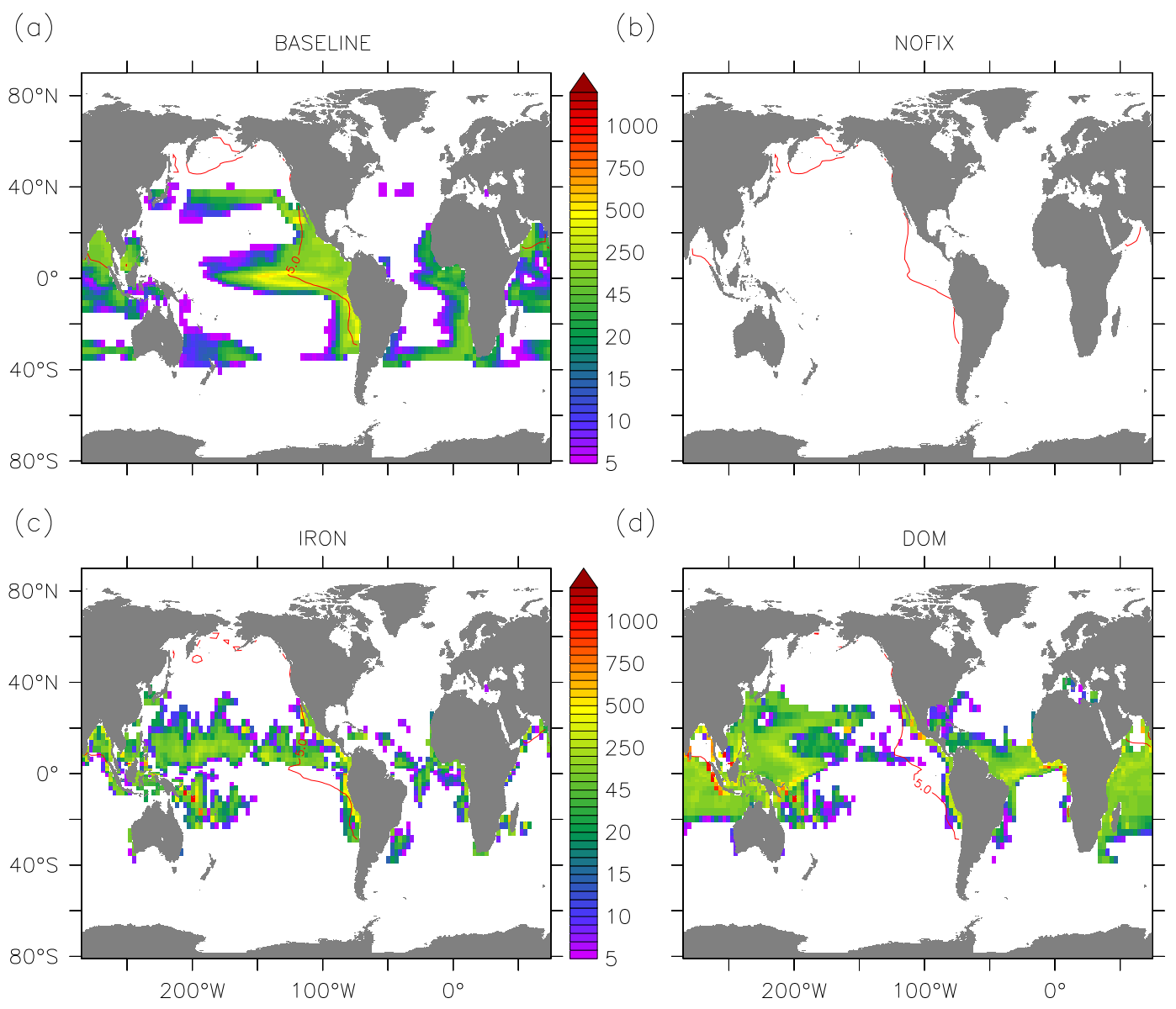

Fig. 2. $\mathrm{N}_{2}$ fixation rates $\left(\mathrm{mmolNm} \mathrm{Nm}^{-2} \mathrm{yr}^{-1}\right.$ ) calculated for the (a) BASELINE, (b) NOFIX, (c) IRON and (d) DOM simulation. Red contour denotes the average position of the $5 \mathrm{mmolm}^{-3} \mathrm{O}_{2}$ isoline at the local vertical minimum of dissolved oxygen. Figure shows averages over 150 model years.

nitrogen. At the core of the vicious cycle is the stoichiometric relation of organic matter undergoing complete denitrification (implicitly including the anammox reaction) (Paulmier et al., 2009):

$$
\begin{aligned}
& \mathrm{C}_{a} \mathrm{H}_{b} \mathrm{O}_{c} \mathrm{~N}_{d} \mathrm{P}+\frac{1}{5}(4 a+b-2 c+5) \mathrm{HNO}_{3} \rightarrow a \mathrm{CO}_{2} \\
& +\frac{1}{10}(4 a+b-2 c+5 d+5) \mathrm{N}_{2}+\mathrm{H}_{3} \mathrm{PO}_{4} \\
& +\frac{1}{5}(2 a+3 b-1 c-5) \mathrm{H}_{2} \mathrm{O}
\end{aligned}
$$

where $a, b, c, d$ are the assumed stoichiometric ratios of organic matter $\mathrm{C}_{a}: \mathrm{H}_{b}: \mathrm{O}_{c}: \mathrm{N}_{d}: \mathrm{P}$. It follows that for each mole of organic nitrogen denitrified, $R_{\mathrm{N}_{\mathrm{loss}}}=\frac{1}{5 d}(4 a+$ $b-2 c+5 d+5$ ) moles of nitrate are lost (Paulmier et al., 2009). For typical organic matter with a stoichiometry of $\mathrm{C}_{106}: \mathrm{H}_{175}: \mathrm{O}_{42}: \mathrm{N}_{16}: \mathrm{P}$ (Anderson, 1995) $R_{\mathrm{N}_{\text {loss }}}=$ 7.5 moles of nitrate are lost for every mole of organic nitrogen denitrified. This implies that in regions where suboxic remineralization is larger than about $1 / 7$ th of the vertically integrated remineralization, any addition of new $\mathrm{N}$ at the sea surface will, upon remineralization of the organic matter, lead to a net loss of fixed N, and a vicious cycle can ensue. Different stoichiometries of OM falling into the OMZ may modulate the magnitude of the $\mathrm{N}$ loss; denitrification of organic matter with elevated carbon content, relative to $\mathrm{C}_{106}: \mathrm{H}_{175}: \mathrm{O}_{42}: \mathrm{N}_{16}: \mathrm{P}$, results in increased $\mathrm{N}$ losses. Denitrification of organic matter with lower $\mathrm{C}: \mathrm{N}$, e.g. algal proteins $\left(\mathrm{C}_{53}: \mathrm{H}_{7}: \mathrm{O}_{23}: \mathrm{N}_{16}\right)$ (Laws, 1991), would, on the other hand reduce the $R_{\mathrm{N}_{\text {loss }}}$ to values as low as 2.2. Plausible stoichiometries of marine organic matter (Laws, 1991), all yield $R_{\mathrm{N}_{\text {loss }}}>1$, and denitrification of organic matter derived from $\mathrm{N}_{2}$-fixation will always lead to a net loss of fixed nitrogen. This implies that $\mathrm{N}_{2}$ fixation cannot compensate for $\mathrm{N}$ losses if the diazotroph-derived organic matter is remineralized via denitrification. Once upwelled to the surface, denitrified waters further stimulate nitrogen fixation closing the vicious cycle (Fig. 1c). In our BASELINE run, where on average approximately $60 \%$ of the simulated $\mathrm{N}_{2}$ fixation occurs above suboxic waters (Fig. 2a), this vicious cycle leads to more $\mathrm{N}$ being denitrified than fixed (Fig. 5d) and a declining total 
$\mathrm{N}$ inventory (Fig. 5a). This result is qualitatively consistent with an idealized box model (Canfield, 2006) of a costal upwelling setting where oxygen minimum waters are depleted in nitrate in the presence of overlying $\mathrm{N}_{2}$ fixation.

A second simulation NOFIX, which differs from the BASELINE run only in that $\mathrm{N}_{2}$ fixation is turned off, provides an estimate of the potential strength of the vicious cycle. As expected, without nitrogen fixation but with denitrification turned on, the model cannot maintain its nitrogen inventory and loses about $4.6 \%$ of the fixed $\mathrm{N}$ within $150 \mathrm{yr}$ (Fig. 5a). This loss is, however, smaller than the net nitrogen loss simulated by the BASELINE experiment $(6.4 \%$, Fig. $5 \mathrm{a})$ where the $\mathrm{N}_{2}$ fixation sustains the vicious cycle. After $150 \mathrm{yr}$, the total $\mathrm{N}$ loss of the BASELINE simulation is about $40 \%$ larger than in experiment NOFIX.

We now test, with additional simulations, how a spatial separation of $\mathrm{N}_{2}$ fixation and denitrification affects the modelled $\mathrm{N}$ inventory. In experiment IRON, growth rates of both diazotrophs and ordinary phytoplankton are reduced in regions where simulated surface $\mathrm{PO}_{4}^{-3}$ concentrations fall below observed monthly mean $\mathrm{PO}_{4}^{-3}$ values taken from the World Ocean Atlas (Conkright et al., 2002), mimicking the effect of iron limitation in our model that does not explicitly resolve the micronutrient iron. When simulating iron limitation, the upwelled excess phosphate is not immediately available to diazotrophs above the OMZ. The growth of $\mathrm{N}_{2}$ fixers in experiment IRON is thus shifted westwards relative to the BASELINE run, thereby contributing to a spatial separation of $\mathrm{N}_{2}$ fixation and denitrification (Fig. 2c). In the 150-yr average, $35 \%$ of the simulated $\mathrm{N}_{2}$ fixation occurs above OMZs in experiment IRON, as compared to $60 \%$ in the BASELINE run. The reduced export and subsequent remineralization of organic material in the $\mathrm{OMZ}$ region leads to a reduction of the modelled oxygen demand and the associated low-oxygen zone (Fig. 6c). The partial shift of areas of $\mathrm{N}_{2}$ fixation away from those of denitrification in experiment IRON reduces the fraction of export production that is remineralized in OMZs relative to the BASELINE simulation (Fig. 7a, b) resulting in a smaller $(5 \%)$ decline of the fixed $\mathrm{N}$ inventory within $150 \mathrm{yr}$ (Fig. 5a, c, d). We investigated the sensitivity of our results to the prescribed iron limitation. A reduction of the iron constraint of the diazotrophs growth rate from $80 \%$ (as used in the IRON experiment) to $50 \%$ results in a $\mathrm{N}$ inventory decrease of $6.4 \%$ instead of $5 \%$ over 150 years. Thus, the magnitude of the $\mathrm{N}$ loss is sensitive to the degree of decoupling of $\mathrm{N}_{2}$ fixation from denitrification induced by our simple parameterization of iron limitation.

A model configuration able to maintain the observed marine nitrogen inventory (Fig. 5a, d) is obtained by including, in addition to iron limitation, a dissolved organic nitrogen (DON) and phosphorus (DOP) pool in experiment DOM. In this simulation, a portion of organic matter is channelled into DON and DOP (Fig. 8), which can be advected away from their source regions and thereby allow for a lateral separa- tion of nutrient fluxes into the surface layer from export of organic matter back into the ocean interior (Fig. 1d). Further in this simulation, DOP is an additional phosphorus source to diazotrophs (Fig. 4d) at very low phosphate concentrations. The DOM configuration permits the transport of the upwelled excess phosphorous signal into areas laterally disconnected from the OMZ allowing for a wider spatial separation of $\mathrm{N}_{2}$ fixation and denitrification (Fig. 2d). During the 150 -yr simulation, only $20 \%$ of the simulated $\mathrm{N}_{2}$ fixation takes place above suboxic waters, as opposed to $35 \%$ and $60 \%$ in the IRON and BASELINE simulations, respectively. This spatial separation of diazotrophic activity from denitrification combined with the vertical separation of dissolved organic matter aerobic remineralization from the deeper depth horizon of the OMZ leads to a drastic reduction of the region where the vicious cycle takes place (Fig. 7c), which, in turn, decreases denitrification rates relative to those of $\mathrm{N}_{2}$ fixation (Fig. 5c, d). On the 150-yr timescale considered in our simulations, the marine $\mathrm{N}$ budget of the DOM model configuration is essentially balanced (Fig. 5a).

The stoichiometry of nitrate consumption during denitrification of organic matter leads to a net loss of fixed nitrogen whenever remineralization of newly fixed organic nitrogen occurs via denitrification in suboxic waters. For Redfield stoichiometry, the vicious cycle can start in any water column where more than $1 / 7$ th of the newly fixed organic nitrogen is remineralized via denitrification. According to the oxygen distribution from the World Ocean Atlas (Bianchi et al., 2012), applying the Martin particle flux curve (Martin et al., 1987) and assuming that organic matter is in Redfield proportion, this may occur in restricted regions of the oceans (Fig. 7d). As the complete loss of inorganic nitrogen is rarely observed in the open ocean (Fig. 7d), the vicious cycle must be efficiently suppressed in reality. Our model analysis suggests that there are factors, such as the combination of iron limitation and DOM dynamics, which contribute to a spatial decoupling of $\mathrm{N}$ sources and sinks that can prevent the vicious cycle from operating on large scales. Additional factors, not fully captured by our model, can further contribute to the spatial separation of $\mathrm{N}$ sources and sinks and can lead to oxic remineralization of newly fixed organic $\mathrm{N}$. This may further reduce the potential for the occurrence of a vicious cycle. For example, more realistic simulated oxygen fields, resulting from the ongoing efforts to improve oceanic circulation in state-of-the-art ocean circulation models (Dietze and Löptien, 2012), are expected to reduce the expansion of OMZ relative to observations (Fig. 6a). Reduction of modelled OMZ would favour oxic remineralization relative to denitrification resulting in a more realistic, reduced potential for the vicious cycle. Nevertheless, with the elevated sensitivity of OMZ variability to small changes in oceanic $\mathrm{O}_{2}$ concentrations (Deutsch et al., 2011), the conditions for a vicious cycle have to be considered if we are to predict the evolution of the $\mathrm{N}$ cycle in a changing environment. 

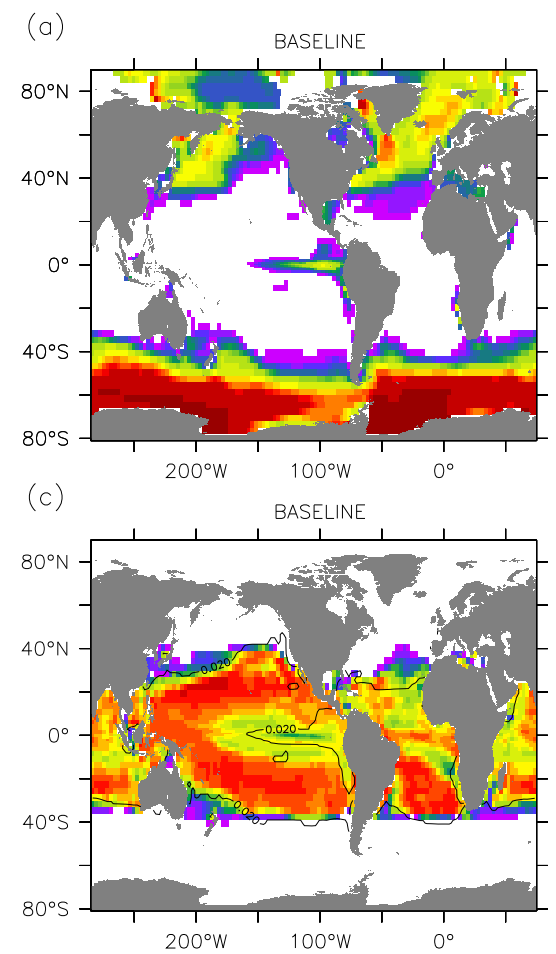

(b)

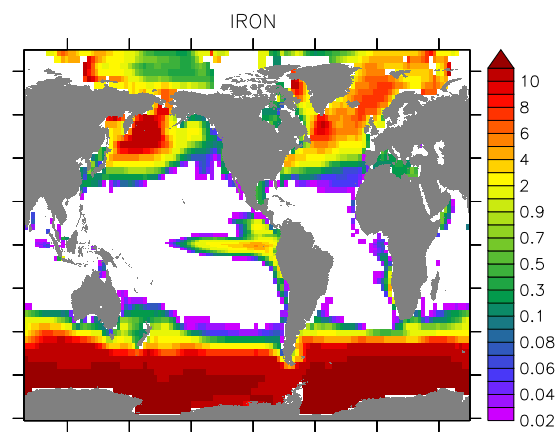

(d)

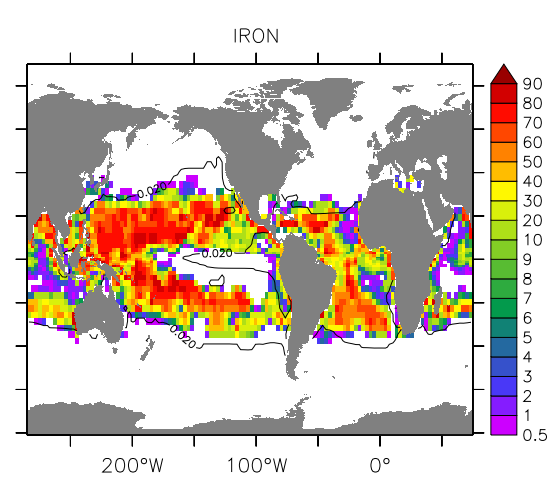

Fig. 3. Average $\mathrm{NO}_{3}^{-}$concentrations $\left(\mathrm{mmolm}^{-3}\right)$ in the upper $50 \mathrm{~m}$ for (a) BASELINE and (b) IRON simulations. Contribution of diazotrophs to total autotrophic production (\%) in (c) BASELINE and (d) IRON simulations. Black contour represents the sea-surface $0.02 \mathrm{mmol} \mathrm{NO}_{3}^{-} \mathrm{m}^{-3}$ isoline. Figure shows averages over 150 model years.
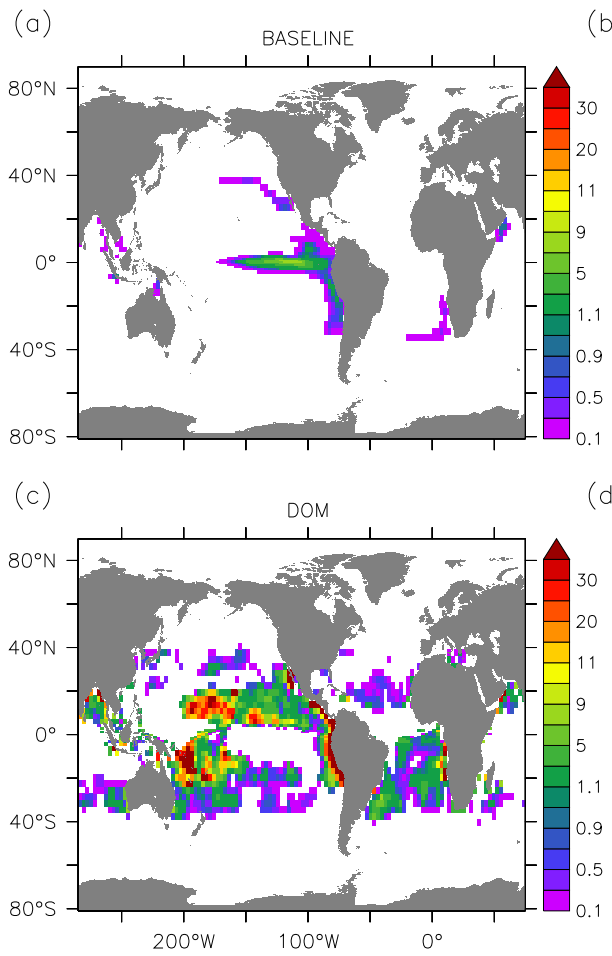

(b)

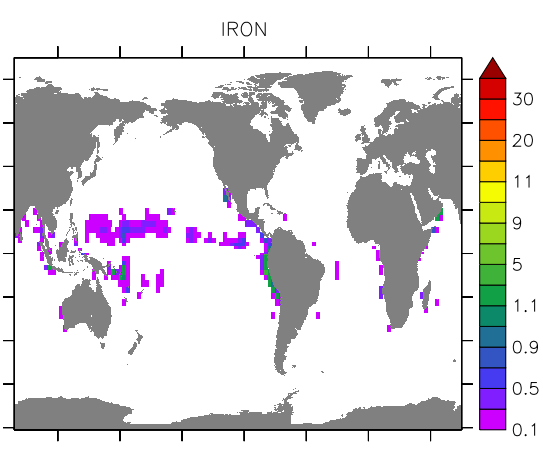

(d)

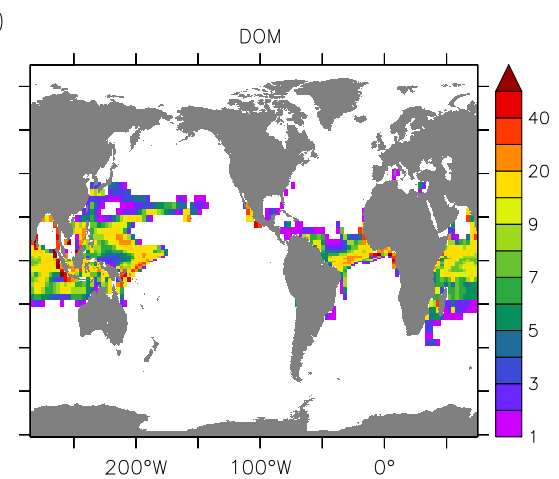

Fig. 4. $\mathrm{NO}_{3}^{-}$uptake of diazotrophs $\left(\mathrm{mmolNm}^{-2} \mathrm{yr}^{-1}\right)$ in the (a) BASELINE (b) IRON and (c) DOM simulations. DOP uptake $\left(\mathrm{mmolPm} \mathrm{Pr}^{-1}\right)$ in the (d) DOM simulation. Figure shows averages over 150 model years. 
(a)

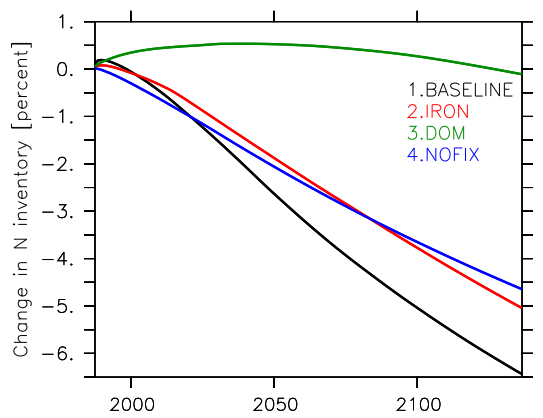

(c)

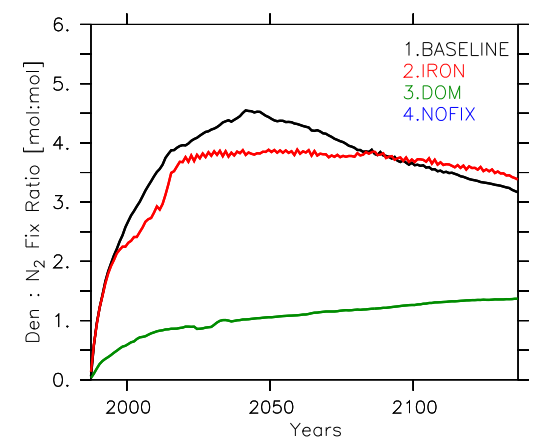

(b)

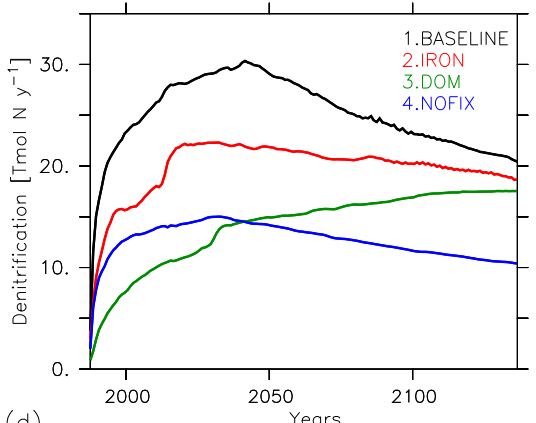

(d)

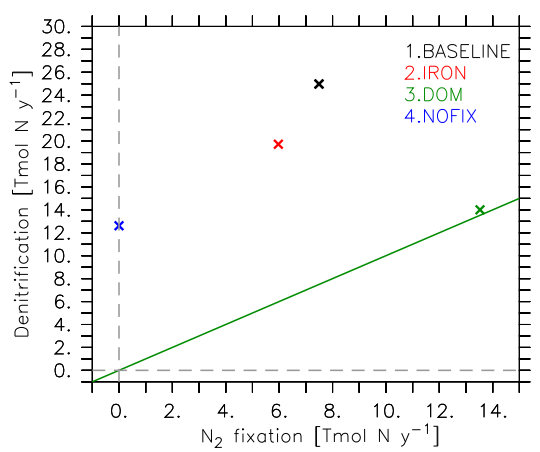

Fig. 5. Temporal evolution of (a) simulated oceanic $\mathrm{N}$ inventory (changes in $\%$ ), (b) global denitrification rates $\left(\mathrm{Tmol}_{\mathrm{Nyr}}{ }^{-1}\right)$, (c) ratio of global denitrification to global $\mathrm{N}_{2}$ fixation (mol : mol). Panel (d) shows scatter plots of the 150-yr mean global denitrification versus 150 -yr mean global $\mathrm{N}_{2}$ fixation for the BASELINE, NOFIX, IRON and DOM simulations. The green line has slope 1 and indicates a balanced oceanic nitrogen inventory.
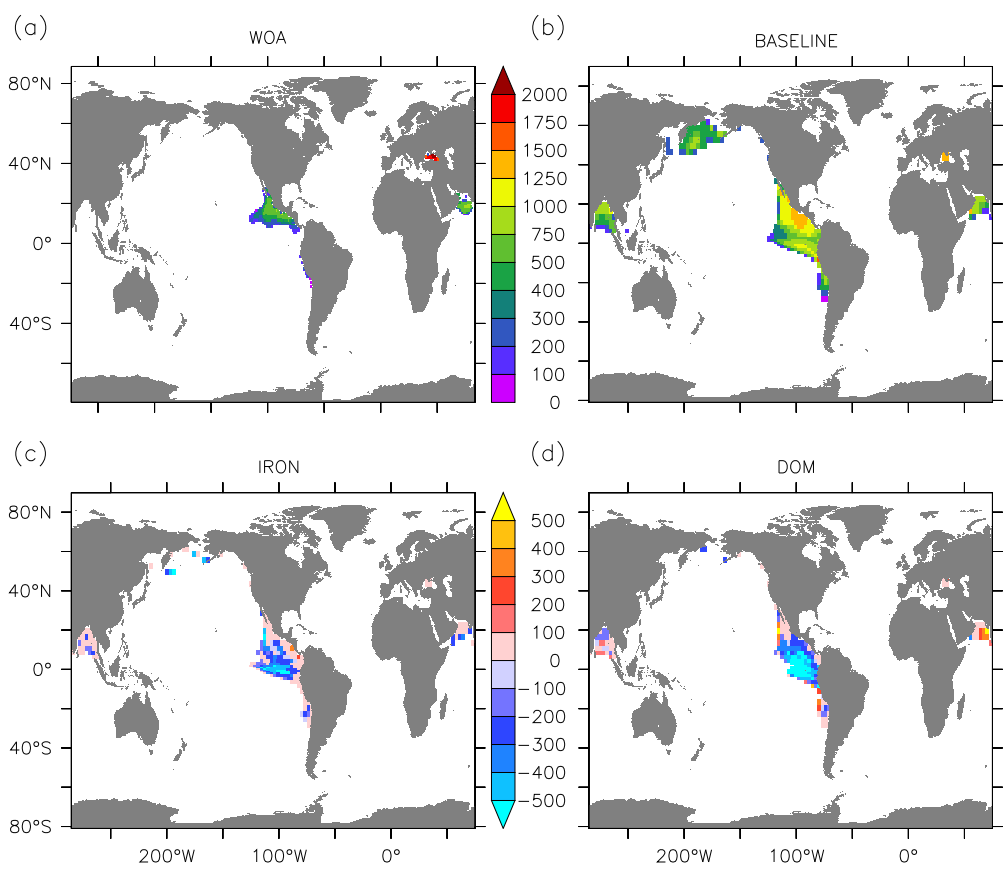

(d)

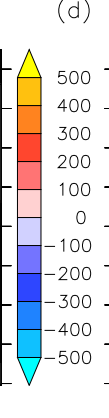

Fig. 6. Average thickness $(\mathrm{m})$ of the low- $\mathrm{O}_{2}$ water layer $\left(\left[\mathrm{O}_{2}\right]<5 \mathrm{mmolm}{ }^{-3}\right)$ computed from the corrected WOA annual means, Bianchi et al. (2012) dataset (panel a) and for the BASELINE simulation (panel b). Panel (c) and (d) are thickness changes of the (c) IRON and (d) DOM simulations relative to the BASELINE simulation. Figure shows averages over 150 model years. Thickness changes are in metres with negative numbers denoting reductions relative to the BASELINE simulation. 

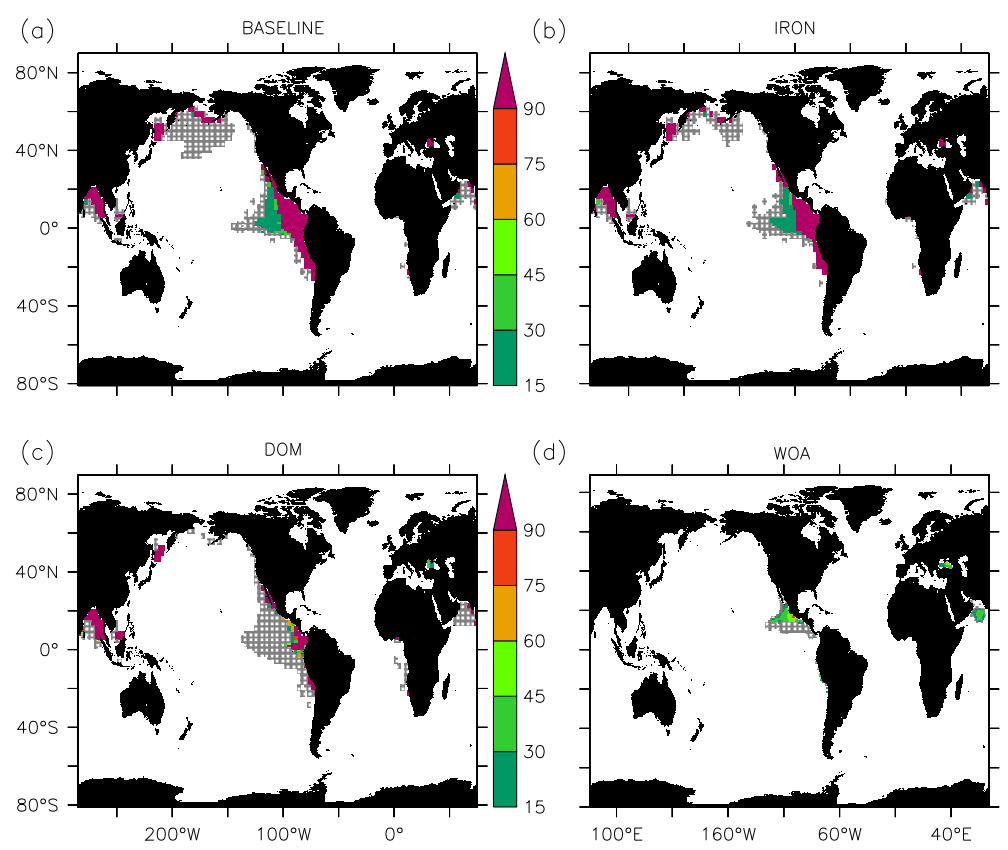

Fig. 7. Percentage of organic matter export remineralized in low oxygen waters $\left(\left[\mathrm{O}_{2}\right]<5 \mathrm{mmolm}^{-3}\right.$ ) for the (a) BASELINE, (b) IRON and (c) DOM simulations. Panels (a), (b) and (c) show averages over 150 model years. Panel (d) shows an estimate of this fraction derived for the real ocean combining the observed oxygen distribution (corrected WOA annual means, (Bianchi et al., 2012)) and a vertical profile of oxygen utilization based on the Martin curve (Martin et al., 1987) of particle flux attenuation. The onset of a vicious cycle can occur in regions where $>15 \%$ of the export is remineralized in suboxic waters (corresponding to coloured regions). Regions where less than $15 \%$ of the export is remineralized in OMZ correspond to the hatched grey areas
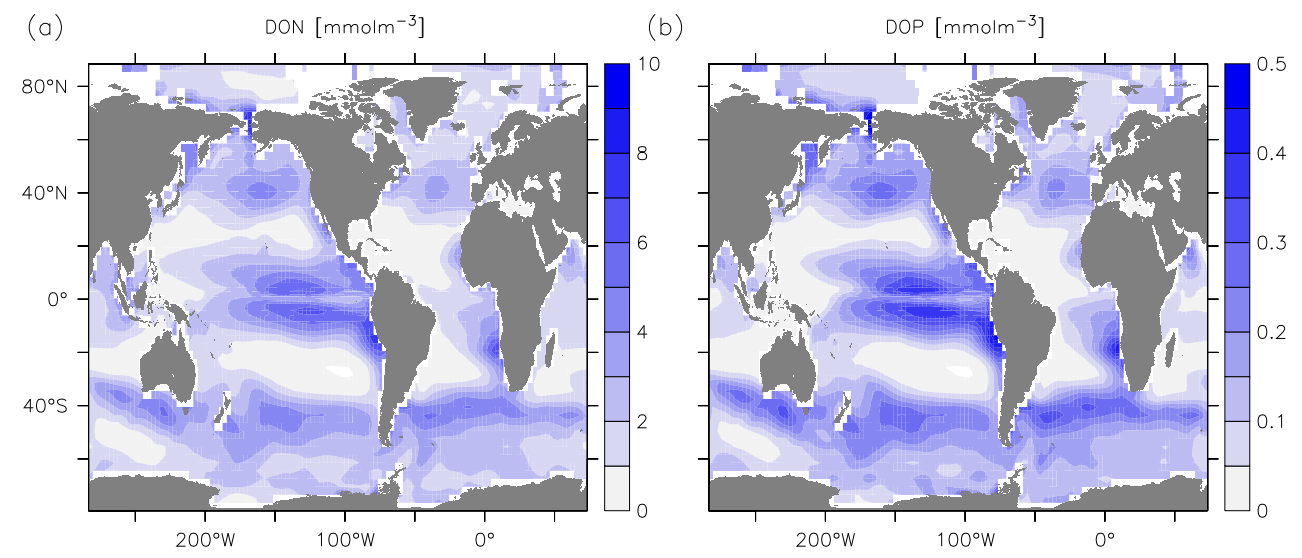

Fig. 8. Average upper ocean $(0-100 \mathrm{~m})$ concentrations of (a) DON and (b) DOP in the DOM simulation. Figure shows averages over 150 model years.

\section{Conclusions}

The tight interaction between denitrification and $\mathrm{N}_{2}$ fixation emerging from the spatial proximity of denitrification and $\mathrm{N}_{2}$ fixation sites gives rise to a vicious cycle where positive feedbacks persist; decreased $\mathrm{N}$ availability occurs proximate to denitrifying areas where excess phosphate stimulates $\mathrm{N}_{2}$ fixation activity (positive feedback). This in turn enhances organic matter export and oxygen consumption at depth, fuelling denitrification further (positive feedback). Because of stoichiometric constraints, any enhancement of $\mathrm{N}_{2}$ fixation results in a net loss of marine nitrogen if a substantial portion of the $\mathrm{N}_{2}$ fixation-derived organic $\mathrm{N}$ is remineralized with $\mathrm{NO}_{3}^{-}$as the ultimate electron acceptor. Factors controlling the growth of diazotrophs, such as iron limitation, and factors that control the fate of the fixed nitrogen, such 
as DOM dynamics and oxygen distributions and transport, allow the disconnection of the flux of $\mathrm{N}_{2}$ fixation-derived organic nitrogen into the low-oxygen areas of denitrification. Accounting for these controls is critical for breaking the vicious cycle that otherwise can be found to lead to a complete regional loss of fixed nitrogen in biogeochemical ocean models (Moore and Doney, 2007; Schmittner et al., 2008). Challenging the common understanding on the stabilizing feedbacks of the marine $\mathrm{N}$ cycle (Codispoti, 1989; Falkowski, 1997; Gruber, 2004; Deutsch et al., 2007; Knapp, 2012), we demonstrate that spatial distance rather than spatial proximity promotes negative feedbacks that stabilize the marine nitrogen inventory. If the vicious cycle is taken into account, the two apparently opposite views of balance of the modern $\mathrm{N}$ inventory (Codispoti et al., 2001; Deutsch et al., 2007) converge. Our results have important implications for understanding the controls on the marine global $\mathrm{N}$ inventory and predicting its response to climate change. We suggest that large changes in the marine $\mathrm{N}$ inventory can be triggered by changes in the spatial arrangement of $\mathrm{N}_{2}$ fixation and $\mathrm{N}$ loss regions and do not need to be initiated by a change in rates of either process. Sources of new nitrogen, via $\mathrm{N}_{2}$ fixation (Deutsch et al., 2007; Fernandez et al., 2011) and atmospheric deposition (Duce et al., 2008), can lead to a net $\mathrm{N}$ loss (Codispoti et al., 2001) rather than a net gain once located within or above oxygen minimum zones. The likely future expansion of ocean areas with surface temperature ranges suitable for $\mathrm{N}_{2}$ fixation (Breitbarth et al., 2007; Moisander et al., 2008), the ongoing expansion of OMZs (Stramma et al., 2008) and the climate-driven changes in dust deposition patterns (Mahowald et al., 2006), all suggest a more intimate spatial coupling of $\mathrm{N}_{2}$ fixation activity to denitrification over the next decades, which may lead to a net loss of marine nitrogen (Codispoti et al., 2001) with consequent impacts on ocean productivity and marine $\mathrm{CO}_{2}$ uptake (Falkowski, 1997). We suggest that any quantitative assessment of past and expected future changes in the marine $\mathrm{N}$ inventory (Codispoti et al., 2001) cannot rely solely on individual estimates of $\mathrm{N}$ loss and $\mathrm{N}$ gain processes, but has to account for their spatial relationship.

\section{Appendix A}

\section{A1 Ecosystem model equations}

Each prognostic variable $C$ is determined following:

$$
\frac{\partial C}{\partial t}=T+\mathrm{sms},
$$

where $T$ represents all diffusive and advective transport terms, sms denotes the source minus sink terms, which describe the biogeochemical interactions as follows:

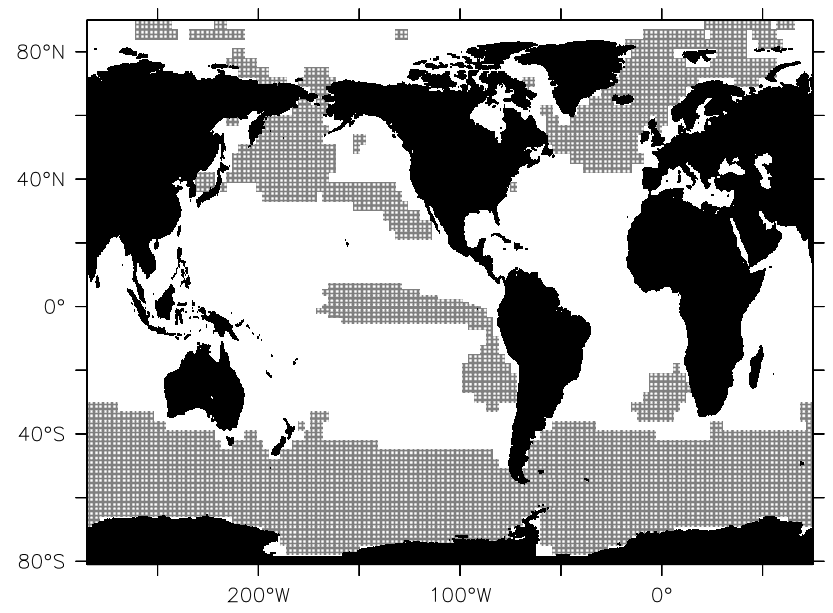

Fig. A1. Diagnosed iron mask (averaged over 150 model years). Shading denotes areas where phytoplankton growth rates in the IRON and DOM simulations are reduced locally such that, simulated surface $\mathrm{PO}_{4}^{-3}$ concentrations do not exceed observed $\mathrm{PO}_{4}^{-3}$ monthly mean concentrations from the World Ocean Atlas (WOA) (Conkright et al., 2002).

Nitrate $\left(\mathrm{NO}_{3}^{-}\right)$equation:

$\operatorname{sms}\left(\mathrm{NO}_{3}^{-}\right)=-\bar{J} \mathrm{P}-u_{\mathrm{N}} \overline{J_{\text {Dia }}} \mathrm{P}_{\text {Dia }}$

$+\left(\mu_{\mathrm{D}_{\mathrm{N}}}\left(1-\sigma_{\mathrm{D}_{\mathrm{N}}}\right) \mathrm{D}_{\mathrm{N}}+\gamma_{2}\left(1-\sigma_{\mathrm{Z}_{\mathrm{e}}}\right) \mathrm{Z}+\mu_{\mathrm{DON}} \mathrm{DON}\right)$

$\left(1-0.8 R_{\mathrm{O}} R^{-1} r_{\mathrm{sox}}{ }^{\mathrm{NO}_{3}}\right)$;

Phosphate $\left(\mathrm{PO}_{4}^{-3}\right)$ equation:

$\operatorname{sms}\left(\mathrm{PO}_{4}^{-3}\right)=\left(+\gamma_{2}\left(1-\sigma_{\mathrm{Z}_{\mathrm{e}}}\right) \mathrm{Z}-\bar{J} \mathrm{P}\right) R^{-1}$

$-\bar{J}_{\text {Dia }} \mathrm{P}_{\text {Dia }} R_{\text {Dia }}{ }^{-1}$

$+\mu_{\mathrm{DP}_{\mathrm{P}}}\left(1-\sigma_{\mathrm{D}_{\mathrm{P}}}\right) \mathrm{D}_{\mathrm{P}}+\mu_{\mathrm{DOP}} \mathrm{DOP}$;

Phytoplankton $(\mathrm{P})$ equation:

$\operatorname{sms}(\mathrm{P})=\bar{J} \mathrm{P}-G(\mathrm{P}) \mathrm{Z}-\mu_{\mathrm{P}} \mathrm{P} ;$

Diazotroph $\left(\mathrm{P}_{\mathrm{Dia}}\right)$ equation:

$\operatorname{sms}\left(\mathrm{P}_{\text {Dia }}\right)=\overline{J_{\text {Dia }}} \mathrm{P}_{\text {Dia }}+\overline{J_{\text {Dia }}{ }_{\text {DOP }}} \mathrm{P}_{\text {Dia }}-G\left(\mathrm{P}_{\text {Dia }}\right) \mathrm{Z}$

$-\mu_{\mathrm{PDia}} \mathrm{P}_{\mathrm{Dia}}$;

Zooplankton (Z) equation:

$\operatorname{sms}(\mathrm{Z})=\gamma_{1} \mathrm{Z}\left(G(\mathrm{P})+G\left(\mathrm{P}_{\text {Dia }}\right)\right)-\gamma_{2} \mathrm{Z}-\mu_{\mathrm{Z}} \mathrm{Z}^{2} ;$

Nitrogen detritus $\left(D_{N}\right)$ equation:

$$
\begin{aligned}
& \operatorname{sms}\left(\mathrm{D}_{\mathrm{N}}\right)=\left(1-\gamma_{1}\right)\left(1-\sigma_{\mathrm{Z}_{\mathrm{s}}}\right)\left(G(\mathrm{P})+G\left(\mathrm{P}_{\mathrm{Dia}}\right)\right) \\
& \mathrm{Z}+\mu_{\mathrm{P}}\left(1-\sigma_{\mathrm{P}_{\mathrm{m}}}\right) \mathrm{P}+\mu_{\mathrm{P}_{\mathrm{Dia}}}\left(1-\sigma_{\mathrm{Dia}_{\mathrm{m}}}\right) \mathrm{P}_{\mathrm{Dia}} \\
& +\mu_{\mathrm{Z}}\left(1-\sigma_{\mathrm{Z}_{\mathrm{m}}}\right) \mathrm{Z}^{2}-\mu_{\mathrm{D}_{\mathrm{N}}} \mathrm{D}_{\mathrm{N}}-w_{\mathrm{s}} \frac{\partial \mathrm{D}_{\mathrm{N}}}{\partial z}
\end{aligned}
$$


Phosphorus detritus $\left(\mathrm{D}_{\mathrm{P}}\right)$ equation:

$$
\begin{aligned}
& \operatorname{sms}\left(\mathrm{D}_{\mathrm{P}}\right)=\left(1-\gamma_{1}\right)\left(1-\sigma_{\mathrm{Z}_{\mathrm{s}}}\right)\left(G(\mathrm{P})+G\left(\mathrm{P}_{\mathrm{Dia}}\right)\right) \mathrm{Z} \\
& +\mu_{\mathrm{P}}\left(1-\sigma_{\mathrm{P}_{\mathrm{m}}}\right) \mathrm{P} \\
& +\mu_{\mathrm{Z}}\left(1-\sigma_{\mathrm{Z}_{\mathrm{m}}}\right) \mathrm{Z}^{2}+\mu_{\mathrm{P}_{\mathrm{Dia}}}\left(1-\sigma_{\mathrm{Dia}_{\mathrm{m}}}\right) \mathrm{P}_{\mathrm{Dia}} R_{\text {Dia }}{ }^{-1} \\
& -\mu_{\mathrm{D}_{\mathrm{P}}} \mathrm{D}_{\mathrm{P}}-w_{\mathrm{s}} \frac{\partial \mathrm{D}_{\mathrm{P}}}{\partial z}
\end{aligned}
$$

Oxygen $\left(\mathrm{O}_{2}\right)$ equation:

$$
\begin{aligned}
& \operatorname{sms}\left(\mathrm{O}_{2}\right)=F_{\text {sfc }}\left(\bar{J} \mathrm{P}+\overline{J_{\text {Dia }}} \mathrm{P}_{\mathrm{Dia}}\left(\mu_{\mathrm{D}_{\mathrm{N}}}\left(1-\sigma_{\mathrm{D}_{\mathrm{N}}}\right) \mathrm{D}_{\mathrm{N}}\right.\right. \\
& \left.\left.+\mu_{\mathrm{DON}} \mathrm{DON}+\gamma_{2}\left(1-\sigma_{\mathrm{Z}_{\mathrm{e}}}\right) \mathrm{Z}\right) r_{\mathrm{sox}}{ }^{\mathrm{O}_{2}}\right) R^{-1} R_{\mathrm{O}} ;
\end{aligned}
$$

Dissolved organic nitrogen equation (DON):

$$
\begin{aligned}
& \operatorname{sms}(\mathrm{DON})=\sigma_{\mathrm{Z}_{\mathrm{s}}}\left(1-\gamma_{1}\right)\left(G(\mathrm{P})+G\left(\mathrm{P}_{\mathrm{Dia}}\right)\right) \mathrm{Z} \\
& +\sigma_{\mathrm{P}_{\mathrm{m}}} \mu_{\mathrm{P}} \mathrm{P}+\sigma_{\mathrm{Z}_{\mathrm{m}}} \mu_{\mathrm{Z}} \mathrm{Z}^{2}+\sigma_{\mathrm{Z}_{\mathrm{e}}} \gamma_{2} \mathrm{Z} \\
& +\sigma_{\mathrm{Dia}_{\mathrm{m}}} \mu_{\mathrm{P}_{\mathrm{Dia}}} \mathrm{P}_{\mathrm{Dia}}+\sigma_{\mathrm{D}_{\mathrm{N}}} \mu_{\mathrm{D}_{\mathrm{N}}} \mathrm{D}_{\mathrm{N}}-\mu_{\mathrm{DON}} \mathrm{DON} ;
\end{aligned}
$$

Dissolved organic phosphorus equation (DOP):

$$
\begin{aligned}
& \operatorname{sms}(\mathrm{DOP})=\left(\sigma_{\mathrm{Z}_{\mathrm{s}}}\left(1-\gamma_{1}\right)\left(G(\mathrm{P})+G\left(\mathrm{P}_{\mathrm{Dia}}\right)\right) \mathrm{Z}\right. \\
& \left.+\sigma_{\mathrm{P}_{\mathrm{m}}} \mu_{\mathrm{P}} \mathrm{P}+\sigma_{\mathrm{Z}_{\mathrm{m}}} \mu_{\mathrm{Z}} \mathrm{Z}^{2}+\sigma_{\mathrm{Z}_{\mathrm{e}}} \gamma_{2} \mathrm{Z}\right) R^{-1} \\
& +\sigma_{\mathrm{Dia}_{\mathrm{m}}} \mu_{\mathrm{P}_{\mathrm{Dia}}} \mathrm{P}_{\mathrm{Dia}} R_{\mathrm{Dia}}{ }^{-1}+\sigma_{\mathrm{D}_{\mathrm{P}}} \mu_{\mathrm{D}_{\mathrm{P}}} \mathrm{D}_{\mathrm{P}}-\mu_{\mathrm{DOP}} \mathrm{DOP} \\
& -\overline{J_{\mathrm{Dia} a_{\mathrm{DOP}}} \mathrm{P}_{\mathrm{Dia}} R_{\mathrm{Dia}}{ }^{-1} .}
\end{aligned}
$$

Sources of dissolved organic nitrogen and phosphorus are (1) fraction of zooplankton sloppy-feeding, (2) fraction of zooplankton excretion, (3) fraction of detritus dissolution, and (4) fraction of phytoplankton, diazotrophos and zooplankton mortality. The latter term mimics the mortality by viral infection and phytoplankton cell leakage, but it is not meant to represent phytoplankton passive exudation which is expected to be dominated by carbohydrates. In the present configuration the fraction of phytoplankton and diazotroph mortality to the DOM compartment is the same. Sinks of DON and DOP are through remineralization, which can be different from one another. Uptake of DOP by diazotrophs can occur when phosphate is lower than $0.005 \mathrm{mmol} \mathrm{m}^{-3}$.

\section{A2 Phytoplankton and diazotroph growth}

The function $\bar{J}=\bar{J}\left(I, \mathrm{NO}_{3}^{-}, \mathrm{PO}_{4}^{-3}\right)$ provides the growth rate of non-diazotrophic phytoplankton determined from irradiance $(I), \mathrm{NO}_{3}^{-}, \mathrm{PO}_{4}^{-3}$,

$$
\bar{J}\left(I, \mathrm{NO}_{3}^{-}, \mathrm{PO}_{4}^{-3}\right)=\min \left(J_{I}, J_{\mathrm{max}} u_{\mathrm{NO}_{3}^{-}}, J_{\max } u_{\mathrm{PO}_{4}^{-3}}\right) .
$$

The maximum growth rate $J_{\max }$ is a function of temperature $(T)$ :

$$
J_{\max }(T)=a_{i} \cdot a \cdot \exp \left(\frac{T}{T_{\mathrm{b}}}\right)
$$

such that growth rates increase by a factor of ten over the temperature range of -2 to $34^{\circ} \mathrm{C}$. We use $a=0.6 \mathrm{~d}^{-1}$ for the maximum growth rate at $0{ }^{\circ} \mathrm{C}$. The maximum growth rate may be reduced by a $a_{i}$ factor when iron limiting conditions apply. Under nutrient-replete conditions, the lightlimited growth rate $J_{I}$ is calculated according to

$$
J_{I}=\frac{J_{\max } \alpha I}{\left(J_{\max }^{2}+(\alpha I)^{2}\right)^{1 / 2}},
$$

where $\alpha$ is the initial slope of the photosynthesis vs. irradiance $(\mathrm{P}-I)$ curve. The calculation of the photosynthetically active shortwave radiation $I$ and the method of averaging the light-limited growth over one day is described in Schmittner et al. (2008). Nutrient limitation is represented by the product of $J_{\max }$ and the nutrient uptake rates $u_{\mathrm{NO}_{3}^{-}}=\left[\mathrm{NO}_{3}^{-}\right] /\left(k_{\mathrm{NO}_{3}^{-}}+\left[\mathrm{NO}_{3}^{-}\right]\right)$and $u_{\mathrm{PO}_{4}^{-3}}=$ $\left[\mathrm{PO}_{4}^{-3}\right] /\left(k_{\mathrm{PO}_{4}^{-3}}+\left[\mathrm{PO}_{4}^{-3}\right]\right)$, with $k_{\mathrm{PO}_{4}^{-3}}=R_{\mathrm{PO}_{4}^{-3}: \mathrm{NO}_{3}^{-}} \times k_{\mathrm{NO}_{3}^{-}}$ providing the respective nutrient uptake rates. Diazotrophs grow according to the same principles as the other phytoplankton, i.e. their light-limited growth rate $J_{I \text { Dia }}$ follows

$J_{I \text { Dia }}=\frac{J_{\max \operatorname{Dia}} \alpha I}{\left[J_{\max \text { Dia }}^{2}+(\alpha I)^{2}\right]^{1 / 2}}$,

but are disadvantaged by a lower maximum growth rate, $J_{\text {max Dia }}$, which is zero below $15^{\circ} \mathrm{C}$ :

$$
J_{\text {max Dia }}=a_{i \text { Dia }} \cdot c_{\text {Dia }} \max \left(0, a\left(\exp \left(\frac{T}{T_{\mathrm{b}}}\right)-2.61\right)\right)
$$

The coefficient $c_{\text {Dia }}$ handicaps diazotrophs by dampening the increase of their maximal growth rate vs. that of other phytoplankton with rising temperature. The maximum growth rate may be reduced by a $a_{i}$ Dia factor when iron limiting conditions apply. Diazotrophs can take up nitrate; however, their growth rate is not limited by $\mathrm{NO}_{3}^{-}$concentrations:

$\overline{J_{\text {Dia }}}\left(I, \mathrm{PO}_{4}^{-3}\right)=\min \left(J_{I \mathrm{Dia}}, J_{\max \mathrm{Dia}} u_{\mathrm{PO}_{4}^{-3}}\right)$.

In addition to phosphate, diazotrophs can take up DOP as a $\mathrm{P}$ source when $\mathrm{PO}_{4}^{-3}$ concentrations are lower than $0.005 \mathrm{mmolPm}^{-3}$;

$\overline{J_{\text {Dia }}}(I, \mathrm{DOP})=\min \left(J_{I \mathrm{Dia}}, J_{\mathrm{max} \text { Dia }} u_{\mathrm{DOP}}\right)$,

where $u_{\mathrm{DOP}}=[\mathrm{DOP}] /\left(k_{\mathrm{DOP}}+[\mathrm{DOP}]\right)$ represents the DOP uptake rate. The low maximum growth rate relative to other phytoplankton, which mimics the high energy demand for fixing $\mathrm{N}_{2}$, makes diazotrophs competitive in $\mathrm{P}$ replete regions.

\section{A3 Remineralization and denitrification}

Particulate organic matter remineralizes to dissolved inorganic nutrients and dissolved organic matter at a constant 
Table A1. Ocean ecosystem model parameters.

\begin{tabular}{|c|c|c|c|}
\hline Ecosystem model parameter & Symbol & Value & Unit \\
\hline \multicolumn{4}{|l|}{ Phytoplankton (P) Coefficients } \\
\hline Initial slope of $\mathrm{P}-I$ curve & $\alpha$ & 0.025 & day $^{-1} /\left(\mathrm{W} \mathrm{m}^{-2}\right)$ \\
\hline Maximum growth rate & $a$ & 0.6 & day $^{-1}$ \\
\hline Iron limiting factor & $a_{i}$ & 0.5 & \\
\hline E-folding temperature of biotic rates & $T_{\mathrm{b}}$ & 15.65 & ${ }^{\circ} \mathrm{C}$ \\
\hline Half-saturation constant for $\mathrm{NO}_{3}^{-}$uptake & $k_{\mathrm{NO}_{3}^{-}}$ & 0.5 & $\mathrm{mmol} \mathrm{m}^{-3}$ \\
\hline Half-saturation constant for $\mathrm{PO}_{4}^{-3}$ uptake & $k_{\mathrm{PO}_{4}^{-3}}$ & 0.3 & $\mathrm{mmol} \mathrm{m}^{-3}$ \\
\hline Specific mortality rate of phytoplankton & $\mu_{\mathrm{P}}^{4}$ & 0.03 & day $^{-1}$ \\
\hline \multicolumn{4}{|l|}{ Diazotroph $\left(\mathrm{P}_{\text {Dia }}\right)$ Coefficients } \\
\hline Dampening of maximal growth rate & $c_{\text {Dia }}$ & 0.5 & \\
\hline Specific mortality rate of diazotrophs & $\mu_{\text {Dia }}$ & 0.02 & day $^{-1}$ \\
\hline Iron limiting factor & $a_{i \mathrm{Dia}}$ & 0.2 & \\
\hline Half-saturation constant for $\mathrm{NO}_{3}^{-}$uptake & $k_{\mathrm{NO}_{3}^{-}}$ & 0.5 & $\mathrm{mmol} \mathrm{m}^{-3}$ \\
\hline Half-saturation constant for $\mathrm{PO}_{4}^{-3}$ uptake & $k_{\mathrm{PO}^{-3}}$ & 0.3 & $\mathrm{mmol} \mathrm{m}^{-3}$ \\
\hline Half-saturation constant for DOP uptake & $k_{\mathrm{DOP}}$ & 0.3 & $\mathrm{mmol} \mathrm{m}^{-3}$ \\
\hline \multicolumn{4}{|l|}{ Zooplankton (Z) Coefficients } \\
\hline Assimilation efficiency & $\gamma_{1}$ & 0.75 & \\
\hline Maximum grazing rate & $g$ & 2.0 & day $^{-1}$ \\
\hline Prey capture rate & $\epsilon$ & 1.0 & $\left(\mathrm{mmol} \mathrm{m}{ }^{-3}\right)^{-2} \mathrm{day}^{-1}$ \\
\hline (Quadratic) mortality & $\mu_{\mathrm{Z}}$ & 0.2 & $\left(\mathrm{mmol} \mathrm{m}{ }^{-3}\right)^{-2}$ day $^{-1}$ \\
\hline Excretion & $\gamma_{2}$ & 0.03 & day $^{-1}$ \\
\hline \multicolumn{4}{|l|}{ DOM Coefficients } \\
\hline Fraction of phy. mortality into DOM & $\sigma_{\mathrm{P}_{\mathrm{m}}}$ & 0.5 & \\
\hline Fraction of dia. mortality into DOM & $\sigma_{\mathrm{Dia}_{\mathrm{m}}}$ & 0.5 & \\
\hline Fraction of zoo. sloppy feeding into DOM & $\sigma_{\mathrm{Z}_{\mathrm{s}}}$ & 0.5 & \\
\hline Fraction of zoo. excretion into DOM & $\sigma_{\mathrm{Z}_{\mathrm{e}}}$ & 0.5 & \\
\hline Fraction of zoo. mortality into DOM & $\sigma_{\mathrm{Z}_{\mathrm{m}}}$ & 0.05 & \\
\hline Fraction of det. $\mathrm{N}$ into DON & $\sigma_{\mathrm{D}_{\mathrm{N}}}$ & 0.1 & \\
\hline Fraction of det. P into DOP & $\sigma_{\mathrm{DP}_{\mathrm{P}}}$ & 0.1 & \\
\hline DON remin. rate & $\mu_{\mathrm{DON}}$ & 0.01 & day $^{-1}$ \\
\hline DOP remin. rate & $\mu_{\mathrm{DOP}}$ & 0.01 & day $^{-1}$ \\
\hline \multicolumn{4}{|l|}{ Detrital (D) Coefficients } \\
\hline Detrital $\mathrm{N}$ remineralization rate & $\mu_{D_{N}}$ & 0.05 & day $^{-1}$ \\
\hline Sinking speed at surface & $w_{\mathrm{D} 0}$ & 7 & $\mathrm{~m} \mathrm{day}^{-1}$ \\
\hline Increase of sinking speed with depth & $m_{w}$ & 0.04 & day $^{-1}$ \\
\hline Maximum sinking speed in water column & $w_{\text {Dmax }}$ & 40 & mday $^{-1}$ \\
\hline Detrital $\mathrm{P}$ remineralization rate & & 0.05 & day $^{-1}$ \\
\hline \multicolumn{4}{|l|}{ Molar elemental ratios } \\
\hline Elemental $\mathrm{O}_{2}: \mathrm{P}$ & $R_{\mathrm{O}}$ & 150 & \\
\hline Phytoplakton elemental N : P & $R$ & 16 & \\
\hline Diazotroph elemental N : P & $R_{\text {Dia }}$ & 16 & \\
\hline
\end{tabular}


remineralization rate $\mu_{\mathrm{D}_{N}}$. In oxic conditions the remineralization of particulate organic matter consumes oxygen assuming fixed elemental ratios $\mathrm{O}_{2}: \mathrm{N}, \mathrm{N}: \mathrm{P}$ and $\mathrm{O}_{2}: \mathrm{P}$ following Anderson (1995) (Table A1), implicitly assuming instantaneous nitrification of $\mathrm{NH}_{4}^{+}$from organic matter remineralization. Oxygen consumption in suboxic waters $(<$ $5 \mu \mathrm{M})$ is inhibited, according to

$r_{\text {sox }} \mathrm{O}_{2}=0.5\left(\tanh \left(\left[\mathrm{O}_{2}\right]-5\right)+1\right)$,

and is replaced by the oxygen-equivalent oxidation of nitrate,

$r_{\mathrm{sox}}{ }^{\mathrm{NO}_{3}}=0.5\left(1-\tanh \left(\left[\mathrm{O}_{2}\right]-5\right)\right)$.

The onset of canonical denitrification starts at $<5 \mathrm{mmolm}^{-3}$ $\mathrm{O}_{2}$ levels and proceeds until $\mathrm{NO}_{3}^{-}$is zero. There is no artificial $\mathrm{NO}_{3}^{-}$threshold as applied elsewhere (Moore and Doney, 2007). As we have fixed stoichiometries (Anderson, 1995), we implicitly assume complete denitrification (implicitly including the anammox reaction). Denitrification consumes nitrate at a rate of $80 \%$ of the molar oxygen equivalent rate, as $\mathrm{NO}_{3}^{-}$is a more efficient oxidant on a mole per mole basis. Oxic and anoxic remineralization stop when both $\mathrm{O}_{2}$ and $\mathrm{NO}_{3}^{-}$become zero. The model does not include sedimentary denitrification. Sinking detritus which accumulates at the ocean floor is remineralized following the same rules which hold everywhere else in the water column.

\section{A4 Grazing}

Zooplankton grazing of Diazotrophs, $G\left(\mathrm{P}_{\mathrm{Dia}}\right)$, and (nonnitrogen-fixing) phytoplankton $G(\mathrm{P})$ is parameterized using a sigmoidal function that allows for multi-species coexistence (Prowe et al. , 2012):

$G\left(\mathrm{P}_{\text {Dia }}\right)=\frac{g \epsilon \mathrm{P}_{\text {Dia }}^{2}}{g+\epsilon \mathrm{P}^{2}+\epsilon \mathrm{P}_{\text {Dia }}^{2}}$

$G(\mathrm{P})=\frac{g \epsilon \mathrm{P}^{2}}{g+\epsilon \mathrm{P}_{\text {Dia }}^{2}+\epsilon \mathrm{P}^{2}}$.

\section{A5 Sinking of Detritus}

The rate of sinking of Detritus $w_{\mathrm{s}}$ is a linear function of depth $z$ but cannot exceed a maximum value of $w_{\text {Dmax }}$ :

$w_{\mathrm{s}}=w_{\mathrm{s}}(z)=\min \left(w_{\mathrm{D} 0}+m_{w} z, w_{\mathrm{Dmax}}\right)$.

Acknowledgements. We are greatful to Iris Kriest and GEOMAR's Biogeochemical Modelling group for fruitful discussions. This work is a contribution of the DFG-supported project SFB754 (www.sfb754.de). Additional support is acknowledged to A. L. from the the Deutsche Forschungsgemeinschaft (LA2919/1-1) and to W. K. from the German Federal Ministry of Education and Research (FKZ 03FO608A, BIOACID).

Edited by: K. Fennel

\section{References}

Altabet, M. A.: Constraints on oceanic $\mathrm{N}$ balance/imbalance from sedimentary $15 \mathrm{~N}$ records, Biogeosciences, 4, 75-86, doi:10.5194/bg-4-75-2007, 2007.

Altabet, M. A., Higginson, M. J., and Murray, D. W.: The effect of millennial-scale changes in Arabian Sea denitrification on atmospheric $\mathrm{CO}_{2}$, Nature, 415, 159-162, 2002.

Anderson, L.: On the hydrogen and oxygen content of marine phytoplankton, Deep-Sea Res. Pt. I, 42, 1675-1680, 1995.

Bianchi, D., Dunne, J. P., Sarmiento, J. L. and Galbraith, E. D.: Data-based estimates of suboxia, denitrification, and $\mathrm{N}_{2} \mathrm{O}$ production in the ocean and their sensitivities to dissolved $\mathrm{O}_{2}$, Global Biogeochem. Cy., 26, GB2009, doi:10.1029/2011GB004209, 2012.

Breitbarth, E., Oschlies, A., and LaRoche, J.: Physiological constraints on the global distribution of Trichodesmium -effect of temperature on diazotrophy, Biogeosciences, 4, 53-61, doi:10.5194/bg-4-53-2007, 2007.

Canfield, D. E.: Models of oxic respiration, denitrification and sulfate reduction in zones of coastal upwelling, Geochim. Cosmochim. Ac., 70, 5753-5765, 2006.

Capone, D. G., Zehr, J. P., Paerl, H. W., Bergman, B., and Carpenter, E. J.: Trichodesmium, a globally significant marine cyanobacterium, Science, 276, 1221-1229, 1997.

Codispoti, L. A.: Phosphorus vs. nitrogen limitation of new and export production, in: Productivity of the Ocean: Present and Past, edited by: Berger, W. H., Smetacek, V. S. and Wefer, G., Wiley, New York, 377-394, 1989.

Codispoti, L. A., Brandes, J. A., Christensen, J. P., Devol, A. H., Naqvi, S. W. A., Paerl, H. W., and Yoshinari, T.: The oceanic fixed nitrogen and nitrous oxide budgets: Moving targets as we enter the Anthropocene?, Sci. Mar., 65, 85-105, 2001.

Conkright, M. E., Locarnini, R. A., Garcia, H. E., O’Brien, T. D., Boyer, T. P., Stephens C., and Antonov J. I.: World Ocean Atlas 2001: Objective Analyses, Data Statistics, and Figures, (CD-ROM Documentation), National Oceanographic Data Centre, Silver Spring, 1-17, 2002.

Delaney, M. L.: Phosphorus accumulation in marine sediments and the oceanic phosphorus cycle, Global Biogeochem. Cy., 12, 563572, 1998.

Deutsch, C., Brix, H., Ito., T., Frenzel, H., and Thompson, L.: Climate-forced variability of ocean hypoxia, Science, 333, 336, doi:10.1126/science.1202422, 2011.

Deutsch, C., Sarmiento, J. L., Sigman, D. M., Gruber, N., and Dunne, J. P.: Spatial coupling of nitrogen inputs and losses in the ocean, Nature, 445, 163-167, 2007.

Devol, A. H.: Denitrification including anammox, in: Nitrogen in the Marine Environment 2 Edn, edited by: Capone, D., Bronk, D., Mulholland, M., and Carpenter, E., Elsevier, Amsterdam, 263-301, 2008.

Dietze H. and Löptien U.: Revisiting "Nutrient Trapping" in global coupled biogeochemical Ocean Circulation Models, Global Biogeochem. Cy., accepted, 2013.

Duce, R. A., LaRoche, J., Altieri, K., Arrigo, K. R., Baker, A. R., Capone, D. G., Cornell, S., Dentener, F., Galloway, J., Ganeshram, R. S., Geider, R. J., Jickells, T., Kuypers, M. M., Langlois, R., Liss, P. S., Liu, S. M., Middelburg, J. J., Moore, C. M., Nickovic, S., Oschlies, A., Pedersen, T., 5 Prospero, J., Schlitzer, R., Seitzinger, S., Sorensen, L. L., Uematsu, M., Ul- 
loa, O., Voss, M., Ward, B., and Zamora, L.: Impacts of atmospheric anthropogenic nitrogen on the open ocean, Science, 320, 893-897, 2008.

Falkowski, P. G.: Evolution of the nitrogen cycle and its influence on the biological sequestration of $\mathrm{CO}_{2}$ in the ocean, Nature, 387 , 272-275, 1997.

Fernandez, C., Farías, L., and Ulloa, O.: Nitrogen fixation in denitrified marine waters, PLoS One, 6, 20539, 2011.

Gnanadesikan, A., Dixon, K. W., Griffies, S. M., Balaji, V., Beesley, J. A., Cooke, W. F., Delworth, T. L., Gerdes, R., Harrison, M. J., Held, I. M., Hurlin, W. J., Lee, H.-C., Liang, Z., Nong, G., Pacanowski, R. C., Rosati, A., Russell, J., Samuels, B. L., Song, S. M., Spelman, M. J., Stouðer, R. J., Sweeney, C. O., Vecchi, G., Winton, M., Wittenberg, A. T., Zeng, F., and Zhang, R.: GFDL's CM2 Global Coupled Climate Models, Part II: The Baseline Ocean Simulation, J. Climate, 19, 675-697, 2006.

Gruber, N.: The dynamics of the marine nitrogen cycle and its influence on atmospheric $\mathrm{CO}_{2}$, in: Carbon Climate Interactions, edited by: Oguz, T. and Follows, M., Kluwer, Dordrecht, 97-148, 2004.

Knapp, A. N.: The sensitivity of marine $\mathrm{N}_{2}$ fixation to dissolved inorganic nitrogen, Frontiers in Microbiology, 3, 1-14, doi:10.3389/fmicb.2012.00374, 2012.

Large, W. and Yeager, S.: Diurnal to decadal global forcing for ocean and sea-ice models: the data sets and flux climatologies, CGD Division of the National Center for Atmospheric Research, 105 pp., 2004.

Laws E. A.: Photosynthetic quotients, new production and net community production in the open ocean, Deep-Sea Res. Pt. I, 38, 143-167, 1991.

Lenton, T. M. and Watson, A. J.: Redfield revisited 1, Regulation of nitrate, phosphate, and oxygen in the ocean, Global Biogeochem. Cy., 14, 225-248, 2000.

Mahowald, N. M., Muhs, D. R., Levis, S., Rasch, P. J, Yoshioka, Zender, C. S., and Luo C.: Change in atmospheric mineral aerosols in response to climate: Last glacial period, preindustrial, modern, and doubled carbon dioxide climates, J. Geophys. Res., 111, D10202, doi:10.1029/2005JD006653, 2006.

Martin, J. H., Knauer, G. A., Karl, D. M., and Broenkow, W. W.: VERTEX: carbon cycling in the Northeast Pacific, Deep-Sea Res., 34, 267-285, 1987.
Mills, M. M. and Arrigo, K.: Magnitude of oceanic nitrogen fixation influenced by the nutrient uptake ratio of phytoplankton, Nature, 3, 412-416, 2010.

Moisander, P. H., Beinart, R. A., Hewson, I., White, A. E., Johnson, K. S., Carlson, C. A., Montoya, J. P., and Zehr, J. P.: Unicellular cyanobacterial distributions broaden the oceanic $\mathrm{N}_{2}$ fixation domain, Science, 327, 1512-1514, 2008.

Moore, J. K. and Doney, S. C.: Iron availability limits the ocean nitrogen inventory stabilizing feedbacks between marine denitrification and nitrogen fixation, Global Biogeochem. Cy., 21, GB2011, doi:10.1029/2006GB002762, 2007.

Moore, C. M., Mills, M. M., Achterberg, E. P., Geider, R. J., LaRoche, J., Lucas, M. I., McDonagh, E. L., Pan, X., Poulton, M., Rijkenberg, J. A., Suggett, D. J., Ussher S. J., and Woodward, E. M. S.: Large-scale distribution of Atlantic nitrogen fixation controlled by iron availability, Nature, 2, 867-871, doi:doi:10.1038/ngeo667, 2009.

Prowe, A. E. F., Pahlow, M., Oschlies, A.: Controls on the diversity-productivity relationship in a marine ecosystem model, Ecological Modelling, 225, 167-176, doi:10.1016/j.ecolmodel.2011.11.018, 2012.

Paulmier, A., Kriest, I., and Oschlies, A.: Stoichiometries of remineralisation and denitrification in global biogeochemical ocean models, Biogeosciences, 6, 923-935, doi:10.5194/bg-6923-2009, 2009.

Redfield, A. C., Ketchum, B. .H., and Richards F. A.: The influence of organisms on the composition of sea water, in: The Sea Vol. 2, edited by: Hill, M. N., Wiley-Interscience, New York, 2677, 1963.

Schmittner, A., Oschlies A., Matthews H. D., and Galbraith E. D.: Future changes in climate, ocean circulation, ecosystems and biogeochemical cycling simulated for a business-as-usual $\mathrm{CO}_{2}$ emission scenario until $4000 \mathrm{AD}$, Global Biogeochem. Cy., 22, GB1013, doi:10.1029/2007GB002953, 2008.

Stramma, L., Johnson, G. C., Sprintall, J., and Mohrholz, V.: Expanding oxygen-minimum zones in the tropical oceans, Science, 320, 655-658, 2008.

Tyrrell, T.: The relative influences of nitrogen and phosphorus on oceanic primary production, Nature, 400, 525-531, 1999. 